\title{
IMPACT OF IN-POND NURSERY OF SHRIMP (Penaeus monodon) POST LARVAE ON THE SURVIVAL RATE AND PRODUCTION UNDER MODIFIED IMPROVED CULTURE SYSTEM
}

\author{
M. L. Islam and M. J. Alam \\ Bangladesh Fisheries Research Institute, Brackishwater Station, Paikgacha \\ Khulna- 9280, Bangladesh
}

\begin{abstract}
To observe the effectiveness of short time in-pond nursery of post larvae (PL) on the survival rate and production of shrimp (Penaeus monodon) under modified improved culture system, an experiment was conducted in earthen ponds at Brackishwater Station of Bangladesh Fisheries Research Institute, Khulna. Results of the experiment revealed that short time in-pond nursery of PL provided the significantly higher $(\mathrm{p}<0.05)$ survival rate $(58 \%)$ than direct stocking of PL (47.81\%) in the rearing pond. In-pond nursery of PL provided $9.95 \%$ better survival rate than direct stocking. The production of shrimp was $661 \mathrm{~kg} / \mathrm{ha}$ under in-pond nursery of PL and it was $534 \mathrm{~kg} / \mathrm{ha}$ under direct stocking of PL in rearing ponds. The production of shrimp was also significantly higher $(p<0.05)$ under in-pond nursery system than direct stocking of PL in rearing ponds. Final weight gain and Food Conversion Ratio (FCR) values were similar in both the treatments. Water quality parameters in both stocking systems were insignificant and it was within the range of shrimp culture. In this study, the increment in production under in-pond nursery system was mainly due to the increase of survival rate in the respective treatment was ascertained.
\end{abstract}

Key words : In-pond nursery, Modified improved culture, Survival, Production, Shrimp

\section{INTRODUCTION}

Shrimp (Penaeus monodon) farming in Bangladesh traditionally started since 1960s, in the low laying tide fed coastal agricultural field with the intension to harvest the naturally introduced shrimp. In mid 1980s, shrimp farming has played an important role in the national economy due to the thriving international market. At that time, some farmers started traditional and improved traditional culture practice to increase per unit production. However, the average production of shrimp from per unit area was not satisfactorily, and it was about $150 \mathrm{~kg} / \mathrm{ha} / \mathrm{yr}$ (Roy et al., 1997). Some of the enthusiastic farmers also started semi-intensive culture practice in late 1980s. Due to invasion of white spot viral diseases, majority of the semi-intensive farms back to improved traditional system and/or culture of fin fishes. Total production of shrimp increased to 64,970 MT in 2002 , and the country earned about US\$ 350 million by exporting about 29,700 MT of processed shrimp in the same year (DoF, 2002). This increase in total shrimp production was due to increase in shrimp farming area. The area under shrimp farming has 
increased from 64,000 ha in $1989-1990$ to 170,000 ha in 2003, with the number of shrimp farms increasing from 10,300 in 1998 to 40,000 in 2003 (DoF, 2002; Nuruzzaman and Muniruzzaman, 2003).

Still the shrimp farmer's in Bangladesh only stock shrimp PL indiscriminately and selectively harvests the adult shrimp, with minimum recovery rate and production (Roy et al., 1997). Somewhere, the farmers supply minimum inputs (lime and fertilizers) and maintain their gher with relatively better water management practice (Milstein et al., 2005). Increasing the recovery rate by adopting any management practice might be the ultimate need at the moment to increase per unit production of shrimp. Stocking with fingerlings and over wintered fingerlings, a proven techniques for promoting survival rate and production in carp culture system (Alam et al., 2002). But, information regarding the fingerling stocking or in-pond nursery of PL in shrimp culture is scares to nil. The results of the present paper reflected the effectiveness of in-pond nursery system of shrimp PL for increasing the survival rate and production under modified improved culture system.

\section{MATERIALS AND METHODS}

The experiment was conducted in earthen ponds having an average area of 0.2 ha each in the pond complex under Brackishwater Station of Bangladesh Fisheries Research Institute situated at Khulna. The study was conducted for a period of 4 months from April- July, 2004.

\section{Experimental design}

The experiment was designed with two treatments: 1) T1- direct stocking of PL in rearing pond and 2) T2- in-pond nursery of PL within nursery enclosure, with three replicates of each. The stocking density of shrimp for the culture pond was considered $5 / \mathrm{m}^{2}$ for both the treatments.

\section{Preparation of nursery enclosure}

For short time in-pond nursery of shrimp post larvae, about $200 \mathrm{~m}^{2}(10 \%)$ area of each pond receiving the respective treatments was enclosed with nylon net fastened with bamboo frame. Bamboo sticks $\left(4 / \mathrm{m}^{2}\right)$ and dried coconut leaves $\left(1 / \mathrm{m}^{2}\right)$ were installed within the nursery enclosure as shelter for the PL, also for the development of periphytonic films.

\section{Pond preparation}

Ponds were prepared through drying and liming the bottom soil with agricultural lime @250 kg/ha. The ponds were fed with tidal water up to a depth of $60-80 \mathrm{~cm}$ and the water was chlorinated with bleaching powder $(20 \mathrm{ppm})$. Then the ponds were fertilized 
with urea @2.5 ppm, TSP@ 3.5 ppm, muriate of potash (MP) @ 0.6 ppm and molasses @ $30 \mathrm{~kg} / \mathrm{ha}$.

\section{Stocking and management of shrimp}

After 7 days of fertilization, the PL (ABW, $0.007 \mathrm{~g}$ ) of P. monodon were stocked as per mentioned design. Shrimps in all ponds were fed with commercial nursery feed (SABINCO) @ $100 \%, 60 \%$, and $30 \%$ of the estimated shrimp biomass for the $1^{\text {st }}, 2^{\text {nd }}$, and $3^{\text {rd }}$ week, respectively. After 18 days of rearing the juveniles within the nursery enclosure in the respective treatments were allowed to spread over the whole pond by up folding the nylon net of nursery enclosure. Afterwards, grow out commercial pellet feed of same company was supplied @ $3-5 \%$ of the estimated shrimp biomass for the rest of the culture period. There was no practice of regular water exchange, except occasional addition to replenish any loss due to evaporation or seepage. As post stocking management, all ponds were limed @ 6 -8 ppm with an equal mixture of $\mathrm{CaCO}_{3}$ and $\mathrm{CaMg}\left(\mathrm{CO}_{3}\right)_{2}$, fortnightly during the entire culture period. Additional liming was also done at the same rate after every heavy rainfall. The ponds were also fertilized with urea @ 0.30-0.50 and TSP 1.00-1.20 ppm at fortnight intervals up to 60 days of culture.

\section{Water quality monitoring}

During the culture period, pond ecological parameters like temperature, transparency, water depth, $\mathrm{pH}$, dissolved oxygen and salinity was monitored biweekly intervals according to APHA (1992) and Strickland and Parsons (1987). Plankton was monitored on monthly interval basis following the methods of Prescott (1987).

\section{Harvesting and data analysis}

After 90 days of rearing, a jumping growth of few shrimps in all the ponds was observed. Final harvesting was done by dewatering the ponds after 110 days of culture. Then growth, survival and production were estimated. ANOVA was done to observe any differences in final weight, survival rate, yield and FCR values within the treatments.

\section{RESULTS AND DISCUSSION}

\section{Pond ecological characteristics}

Results on water quality parameters have been presented in Table 1 . Water $\mathrm{pH}$ in all the ponds was alkaline in condition. Alkaline water is more suitable for aquaculture rather than neutral or acidic. Acidic water restricted the growth of primary producer and reduces feeding affinity of shrimp (Boyd, 1989). Variation in $\mathrm{pH}$ in the present trial was within an optimum range (8.0-8.9) and congenial for shrimp culture for the entire period avoiding any unionized $\mathrm{NH}_{3}-\mathrm{N}$ toxicity for prawn $(\mathrm{New}, 1995)$.

Temperature was very high $\left(37.0^{\circ} \mathrm{C}\right)$ during stocking but decreased sharply to the lowest level $\left(26.50^{\circ} \mathrm{C}\right)$ at 30 days of culture (Fig.1). At that time, dissolved oxygen decreased to its lowest level of $4.0 \mathrm{mg} / 1$ (Fig. 2) and transparency increased to its highest level (Fig. 3). Dissolved oxygen in aquaculture inversely related to temperature (Boyd, 1988). But in the 
present trial, both temperature and dissolved oxygen flops at the same time. Dissolved oxygen in aquaculture might decreased due to increased bacterial activity on the organic matter (Saha, 2000) at higher temperature or due to restrictions in photosynthesis during long term cloudy weather by crushing of primary producers leads to increased the transparency of water in the present trial. Temperature, dissolved oxygen and water transparency in the present trial was greatly influenced by cloudy weather at that time. However, the DO values remained above sub-optimal levels $(>4 \mathrm{mg} / \mathrm{l})$, avoiding environmental stress to shrimp (Chanratchakool et al., 1995).

Table 1 . Mean \pm SD and ranges of water quality parameters of the ponds under different stocking system

\begin{tabular}{l|c|c}
\hline \multirow{2}{*}{ Parameters } & \multicolumn{2}{|c}{ Treatments } \\
\cline { 2 - 3 } & $\mathrm{T}_{1}$ & $\mathrm{~T}_{2}$ \\
& (Direct stocking of PL) & (In-pond nursery of PL) \\
\hline Depth $(\mathrm{cm})$ & $83.81 \pm 11.422$ & $97.37 \pm 14.83$ \\
Temperature $\left({ }^{\circ} \mathrm{C}\right)$ & $(63-100)$ & $(70-110)$ \\
& $31.41 \pm 2.84$ & $31.14 \pm 2.68$ \\
Transparency $(\mathrm{cm})$ & $(26.5-37.0)$ & $(26.5-36.0)$ \\
& $26.84 \pm 5.48$ & $26.78 \pm 4.84$ \\
Salinity (ppt) & $(20.0-43.0)$ & $(19.5-35.0)$ \\
& $9.59 \pm 5.68$ & $9.43 \pm 5.87$ \\
pH & $(2.0-17.0)$ & $(2.0-17.0)$ \\
& $8.48 \pm 0.29$ & $8.37 \pm 0.21$ \\
Dissolved oxygen $(\mathrm{mg} / \mathrm{l})$ & $(8.0-8.9)$ & $(8.1-8.7)$ \\
& $4.95 \pm 0.457$ & $4.95 \pm 0.49$
\end{tabular}

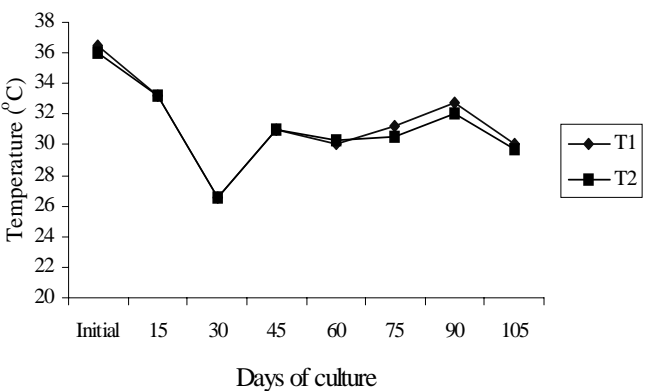

Fig. 1. Temperature regime of water under different treatments

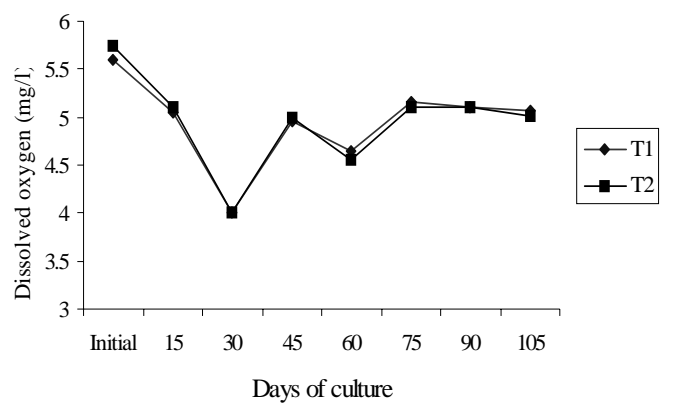

Fig. 2. Status of dissolved oxygen under different stocking systems 
As shown in Fig. 4, the stocking of shrimp was done at a salinity level of 17.0 ppt, which gradually decreased to $2.0 \mathrm{ppt}$ at the end of culture period due to subsequent dilution of the pond water by the rain water of the monsoon. Among water quality parameters, salinity is the most considerable factor for culture of marine tiger shrimp. Karthikeyan (1994) recommended the salinity level of 10-30ppt, whereas, Chanratchakool et al. (1994) mentioned favorable salinity of 15-20ppt for tiger shrimp culture. However, in the present trial, a gradual lowering salinity with increasing the culture duration did not negatively affected the growth and health condition of shrimp. The observation on salinity in the present trial is strongly supported by the observation of Saha et al. (1999).

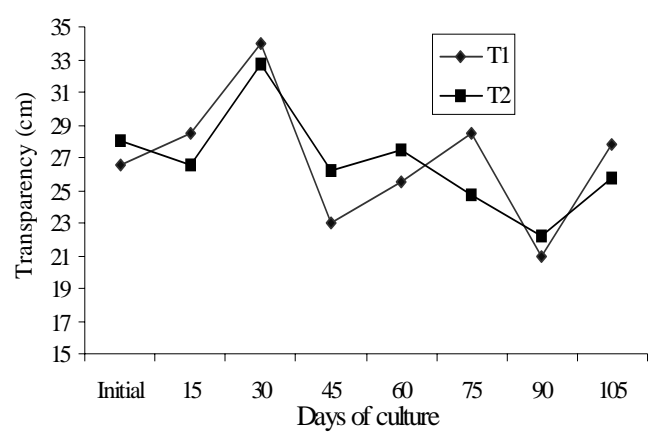

Fig. 3. Trend of water transparency under different treatments

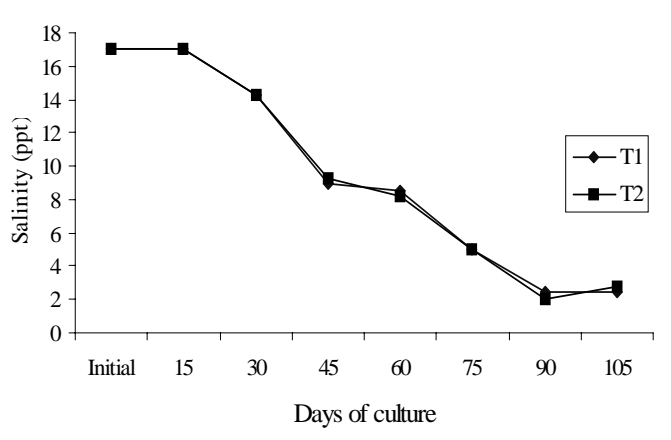

Fig. 4. Status of salinity under different treatments during culture period

The concentration of phytoplankton decreased at 30 days of culture (June), but increased sharply afterwards (Fig. 5). Heavy rainfall caused subsequent dilution of water and crushing of phytoplankton by cloudy weather may cause lowered phytoplankton concentration. On the other hand, concentration of zooplankton was in stable condition throughout the culture period (Fig. 6) and was almost similar in both the treatments.

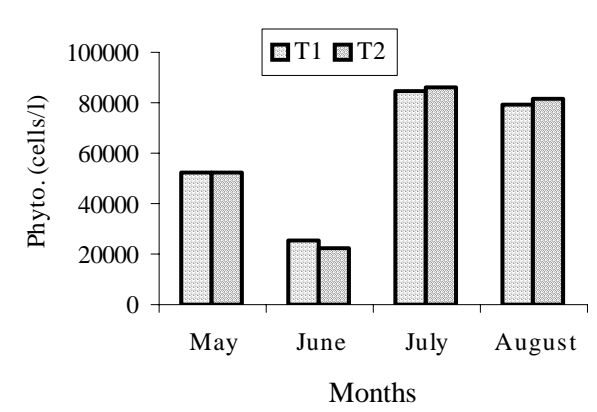

Fig. 5. Concentration of phytoplankton under different treatments

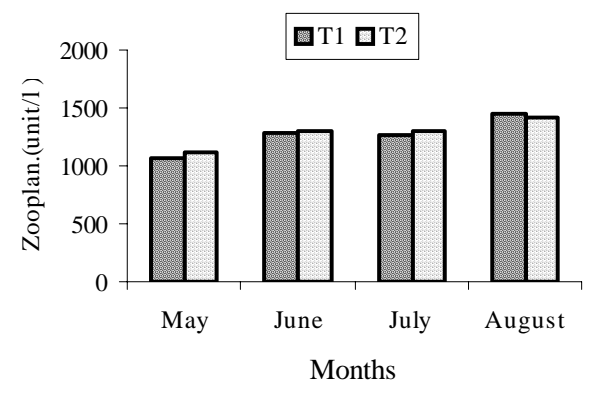

Fig. 6. Zooplankton concentration under different treatments 
In the present study, variations in different water quality parameters were observed more or less similar in both the treatments for the entire culture period. However, variations in values of different water quality parameters in the present trial were within the optimum range for freshwater prawn culture (New, 1995) and for shrimp culture (Chakraborti et al., 1985; Chanratchakool et al., 1995; Hariati et al., 1996), creating a favorable environment for primary productivity and plankton production.

\section{Growth and production of shrimp}

Results for growth and production of shrimp are presented in Table 2. After 110 days of rearing, the survival rate of shrimp was $57.76 \%$ under in-pond nursery system. But it was $47.81 \%$ under direct stocking system. The overall survival rates of shrimp in both the treatment was very low than the observation of Alam et al. (1997), who reported the survival rate of $84 \%$ for freshwater prawn in hapa-net nursery with the stocking density of $250 / \mathrm{m}^{2}$. Survival rate of shrimp might be reduced due to improper acclimatization during stocking, uncongenial ecological conditions at culture period, disease outbreak and predation. In this experiment, the lower survival rate of shrimp was might be due to the entrance of swimming crabs in all the experimental ponds and subsequently predation of shrimp by the crabs. Borremans and Redant (1983) from their short time experiment reported about $2 \%$ of shrimp was being eaten by the predatory nature of swimming crab, Macropipus holsatus. However, the survival rate of shrimp was much higher than Apud et al. (1984), who reported the survival rate of $37.5 \%$ in pond of $40-70$ cm depth.

Table 2. Production performance of shrimp (Penaeus monodon) in ponds under different stocking patterns

\begin{tabular}{l|c|c}
\hline \multicolumn{1}{c|}{ Particulars } & $\begin{array}{c}\mathrm{T}_{1} \\
\text { (Direct stocking of PL) }\end{array}$ & $\begin{array}{c}\mathrm{T}_{2} \\
\text { (In-pond nursery of PL) }\end{array}$ \\
\hline Initial weight (g) & 0.007 & 0.007 \\
Weight (g) after nursery period & 0.0761 & 0.084 \\
Final weight (g) & $22.38 \pm 6.236$ & $22.89 \pm 5.782$ \\
Survival rate (\%) & $47.81 \pm 3.304^{\mathrm{b}}$ & $57.76 \pm 2.451^{\mathrm{a}}$ \\
Yield (kg/ha) & $534.42 \pm 27.81 \mathrm{~b}$ & $660.69 \pm 15.35 \mathrm{a}$ \\
FCR & $1.90 \pm 0.026$ & $1.92 \pm 0.020$ \\
\hline
\end{tabular}

Figures with different superscript in the same row differs significantly

Despite of lower survival rate in all the treatments, the survival rate of shrimp was significantly higher $(\mathrm{p}<0.05)$ under in-pond nursery system than direct stocking (Table 3) and in-pond nursery provided $9.95 \%$ better survivability than direct stocking of PL. The higher survival rate under in-pond nursery system was might be the positive impact of nursery enclosure. In the nursery enclosure, shrimp PL were reared for short time within a limited area which ensured available supplementary feed to them. The bamboo sticks and dried leafs provided shelter for the PL. Periphytonic film grown on the refuges and 
nursery enclosure might be used as initial feed for the PL like that of the periphyton based carp culture mentioned by Azim et al. (2001); Wahab et al. (1999). In-pond nursery of PL might be also provided an extra benefit of minimizing the transfer stress and transfer mortality.

Final weight gain $(\mathrm{g})$ and FCR values were similar in both the treatments. The production of shrimp was $660.69 \mathrm{~kg} / \mathrm{ha}$ under in-pond nursery system (T2) and it was $534.42 \mathrm{~kg} / \mathrm{ha}$ in direct stocking (T1) of PL (Table 2). The production of shrimp was significantly higher $(\mathrm{p}<0.05)$ under in-pond nursery system (T2) than direct stocking (T1) in the cultured pond (Table 3). The increase in production under in-pond nursery system was mainly due to increased survival rate in the respective treatment. Average production of shrimp obtained in present experiment is quite higher than that of Apud et al. (1984), who reported an average yield of $340 \mathrm{~kg} / \mathrm{ha} / \mathrm{crop}$ at stocking rate of $4-5 / \mathrm{m}^{2}$ in monoculture with supplemental feed including improved water management. The production of shrimp $385.43 \mathrm{~kg} / \mathrm{ha} / \mathrm{crop}$ was also reported by Ahmed et al. (2000).

Table 3. ANOVA of different production parameters under different stocking patterns

\begin{tabular}{l|c|c|c}
\hline \multirow{2}{*}{ Parameters } & \multicolumn{3}{|c}{ Source of variance } \\
\cline { 2 - 4 } & MS & Direct stocking Vs In-pond nursery \\
\cline { 2 - 4 } & 0.39015 & 0.909017 & P value \\
\hline Final weight & 148.5038 & 17.55436 & 0.394366 \\
Survival rate & 23917.43 & 47.40718 & $0.013809^{*}$ \\
Production & 0.0006 & 1.090909 & $0.002332^{*}$ \\
FCR & & & 0.355232 \\
\hline
\end{tabular}

* Significant at $5 \%$ level

\section{CONCLUSION AND RECOMMENDATION}

In traditional shrimp culture system, farmers indiscriminately stock shrimp PL in the gher. Despite of no incidence of disease outbreak during culture period, the recovery rate of shrimp seemed very poor. Such low return rate often caused financial losses which demoralized them in future culture. But they did not know the ultimate cause of low survival rate. Among various causes inadequate conditioning of PL to pond water and improper nursery at initial stage might be the remarkable factor of sudden death of PL which leaded low survival rate and production of shrimp. The finding of the present trial focused that; in-pond nursery of PL might be one of the important culture tools for promoting the survival rate and production of shrimp under modified improved culture system. In case of gher condition it must be better to prepare an earthen nursery attached to the rearing gher to reduce the incidence of unwanted aquatic animals. 


\section{ACKNOWLEDGEMENT}

The authors would like to express their sincere gratitude to the Authority of Bangladesh Fisheries Research Institute for providing research support. The BARC (Bangladesh Agricultural Research Council) is also greatly acknowledged for supplementary funding to carry out the research work.

\section{REFERENCES}

Ahmed, S. U., Shofiquzzoha, A. F. M., Saha, M. R. and Islam, M. S. 2000. Water quality management on the enhancement of shrimp (Penaeus monodon Fab.) production in the traditional and improved-traditional ghers of Bangladesh. Bangladesh J. Fish. Res., 4(1): 63-68.

Alam, M. J., Hoq, M. E., Jahan, D. A. and Mazid, M. A. 1997. Nursery rearing of Macrobrachium rosenbergii (de Man) using hapa-nets: effects of stocking density. Bangladesh J. Fish. Res., 1(1): 09-16.

APHA (American Public Health Association) 1992. Standard Methods for The Examination of Water and Wastewater. 18th ed., APHA, Washington, DC. p. 1266.

Apud, F. D., Gonzales, K. and Deatras, N. 1984. Survival, growth and production of Penaeus monodon fabricus at different stocking densities in earthen ponds with flow-through systems and supplemental feeding. Fish. Res. J. Philippines, 6(2): 1-9.

Azim, M. E., Wahab, M. A., van Dam, A. A., Beveridge, M. C. M., Milstein, A. and Verdegem, M. C. J. 2001. Optimization of fertilization rate for maximizing periphyton production on artificial substrates and the implications for periphyton-based aquaculture. Aquacult. Res. 32: 749-760.

Borremans, C. and Redant, F. (1983). In vitro experiments on the predation by the swimming crab, Macropipus holsatus, on brine shrimps, Crangon crangon. ICES Shellfish Commitee, C.M., 19: $1-7$.

Boyd, C.E. 1989. Water quality management and Aeration in Shrimp Farming. Fisheries and Allied Aquaculture Development Series No. 2, Alabama Agricultural Experiment Station, Auburn University, Alabana, 83 pp.

Boyd, C.E. 1988. Water quality management for pond fish culture. Elsvier, New York.

Chakraborti, RK, Ravichandran, P., Halder, D.D., Mandal, S.K. and Sanfui, D. 1985. Some physicochemical characteristics of Kakdwip brackishwater ponds and their influence on survival, growth and production of Penaeus monodon (Fabricius). Indian J. Fish., 32(2): 224-235.

Chanratchakool, P., Turnbull, J.F. and Limsunean, C. 1994. Health management in shrimp ponds. Aquatic Animal Health Research Institute, Department of Fisheries, Kasetsart University, Bangkok. 91 pp.

Chanratchakool, P., Turnbull, J. F., Funge-Smith, S., and Limsuwan. C. 1995. Health management in shrimp ponds. $2^{\text {nd }}$ edition. Aquatic Animal Health Institute, Thailand. 112 p.

DoF (Department of Fisheries) 2002. Fish Week Compendium. Department of Fisheries, Ministry of Fisheries and Livestock, Dhaka, Bangladesh, p. 57.

Hariati, A. M., Wiadnya, D. G. R., Tanck, M. W. T., Boon, J. H. and Verdegem, M. C. J. 1996. Penaeus monodon (Fabricius) production related to water quality in East Java, Indonesia. Aquacult. Res., 27: 255-260.

Karthikeyan, J. 1994. Aquaculture (shrimp farming)- its influence on environment. Proc. Sem."Our Environment, its Challenges to Development Projects". Sept. 9-10, 1994. Organized by American Society of Engineers and Jadavpur University, held at Calcutta. pp. JK 1-7. 
Milstein, A., Islam, M. S., Wahab, M. A., Kamal, A. H. M. and Dewan, S. 2005. Characterization of watr quality in shrimp ponds of different sizes and with different management regimes using multivariate statistical analysis. Aquaculture International. 13: 501-518.

New, M. B. 1995. Status of fresh water prawn farming: a review. Aquacult. Res., 26: 1-54.

Nuruzzaman, M. and Muniruzzaman, M. 2003. Impact of shrimp industry on coastal communities. Paper presented in the Workshop on Present Status of Coastal and Marine Resources of Bangladesh and Future Potentials for Poverty Alleviation held in BRAC Auditorium, Mohakhali, Dhaka, Bangladesh, April 27, 2003.

Prescott, G. W. 1987. Algae of the Western Great Lakes area. (Wn. C. Brawn Co. Inc. Dubuque, Iowa, pp. 986.

Roy, P. K., Ahmed, S. U. and Shofikuzzoha, A. F. M. 1997. Optimization of stocking density for environmental friendly improved extensive shrimp farming system in South-west part of Bangladesh. Bangladesh J. Fish. Res., 3(2): 137-143.

Saha, S.B. 2000. Oxygen consumption pattern of some common manures used in pond fertilization. Bangladesh J. Agri., 25(1\&2): 97-102.

Saha, S.B., Bhattacharrya, S.B. and Choudhury, A. 1999. Production potential of Penaeus monodon (Fab.) in low saline environment. J. Aqua. Trop., 14(4): 319-325.

Strickland, J. D. H. and Parsons, T. R. 1987. A practical handbook of seawater analysis. Bull. Fish. Res. Bd. Canada, Ottawa, Canada., 167: 311 p.

Wahab, M. A., Azim, M. E., Ali, M. H., Beveridge, M. C. M. and Khan, S. 1999. The potential of periphyton-based culture of the native major carp Kalbasu, Labeo calbasu (Hamilton). Aquacult. Res., 30: 409-419. 